\title{
POLITICAL LIFE AND THE AGRARIAN QUESTION IN THE COLUMNS OF THE UKRAINIAN CERENIST NEWSPAPER "KHLIBOROBSKA PRAVDA" (THE SECOND HALF OF THE 1920S)
}

\section{Ilnytskyi V. I., Hlibischuk M. V.}

\section{INTRODUCTION}

According to Western researcher Eric Hobsbawm, who is considered one of the most famous historians of the last century, the "short twentieth century" was an era of extremes, where liberal democracy was on one pole and totalitarianism on the other ${ }^{1}$. These two models of socio-political development, according to E. Hobsbawm, were the alternatives faced by human civilization in the twentieth century. Of course, the British scholar aptly noted one of the key features of the past historical epoch, but to say that there are only two ways to build the political, social and economic structure of states, in our opinion, is a significant simplification. After all, the history of the twentieth century. was extremely rich in the existence of various socio-political and socio-economic models of development.

One of the historical alternatives mentioned above was agrarianism, which became widespread in Central and Eastern Europe in the late 19th and early 20th centuries. This political and socio-economic doctrine was especially popular in the countries of this region in the interwar period, when after the end of the Great War of 1914-1918 new countries were formed in the post-imperial space. Of course, we explain this influence of agrarianism not only by the agricultural specifics of these territories but also by the beliefs of the peasants at that time, who were the most numerous social community. As Joseph Rothschild rightly points out, the peasant's travels and his trials as a mobilized soldier in World War I not only deprived him of naivety about material needs but also showed him how much power and the urban population depended on his cleverness and labour ${ }^{2}$. We should also not forget that the electoral systems of these newly created states, despite their shortcomings and imperfections, turned the peasants into the largest group of voters, on whose preferences depended on the political future of a particular regime.

1 Гобсбаум Е. Вік екстремізму. Коротка історія ХХ віку. 1914-1991. Київ : Альтернатива, 2001. 544 с.

${ }^{2}$ Ротшильд Дж. Східно-Центральна Європа між двома світовими війнами. Київ : Мегатайп. С. 27. 
The research aims to consider how political life and the agrarian issue were covered in the Ukrainian newspaper "Khliborobska Pravda", which was the official publication of the Cerenist party in Northern Bukovina and Northern Bessarabia. The choice of this source is conditioned not only by the circumstances mentioned by us but also by the fact that during this period "Khliborobska Pravda" reflected the ideas of Ukrainian politicians who entered into a temporary unification agreement with the National Cerenist bloc. The views of Ukrainian and Romanian representatives of this political vector on agrarian, national and other important issues of the time created a certain ideological basis for cooperation. As for the chronological boundaries of our scientific article, they cover the second half of the 1920s. This author's position is due to several considerations. The lower limit is in 1926 a manifesto on their unification was signed between the Cerenist and national parties, which at that time were considered one of the most important opposition political forces to the Romanian government, which led to the creation of a joint opposition camp to political authorities. Upper with the beginning of the "Great Depression" of 1929-1933, which led to the revision of some ideological principles of this political bloc. In addition, it was during this period that the coalition of the above-mentioned parties won the parliamentary elections and formed a new government.

Briefly analyzing the coverage of this topic in the scientific works of historians, we note that researchers have briefly dealt with this issue. Some researchers have tried to characterize the agrarian question in interwar Romania by partially involving newspaper articles. In particular, some Soviet scholars as V. Malinskyi ${ }^{3}$, V. Litvinov ${ }^{4,5}$, S. Kobylyanskyi ${ }^{6}$. Foreign researchers also partially used the materials of the metioned publication and other newspapers of that time. We see this in the works of historians such as A. Nicolaescu ${ }^{7}$. It should also be noted that some contemporary Ukrainian

3 Малинский В. Аграрная реформа 1918-1924 гг. в Бессарабии. Кишинев, 1949. $144 \mathrm{c}$.

${ }^{4}$ Литвинов В.К. Становище селян Буковини в боярській Румунії (1918-1939). Наукові записки ЧДУ. Серія історичних наук. Львів: Вид-во Львів, держ. ун-ту, 1956. T. 18. С. 55-68.

Литвинов В.К. Аграрная реформа на Буковине во время румынской оккупации 1921-1926. Тезисы докладов ХIII отчетной научной сессии профессорско-преподавательского состава. Черновицкий государственный ун-т. Черновцы, 1957. С. 69-70.

${ }^{5}$ Ibid.

${ }^{6}$ Кобилянський С. 3 історії проведення аграрної реформи на Північній Буковині під час окупації краю буржуазно-поміщицькою Румунією. Минуле $i$ сучасне Північної Буковини. Київ : Наукова думка, 1972. Вип. 1. С. 40-51.

${ }^{7}$ Nicolaescu A. Evoluţia editorială a gazetei Ţărănismul în primii doi ani de existentă (1925-1927) Studia Universitatis Cibiniensis. Series Historica. 2018. № 15. P. 173-199. 
historians who study various aspects of the history of the Kingdom of Romania in the interwar period involve newspaper publications of "Khliborobska Pravda" in their works. These are the works of I. Piddubnyi ${ }^{8}$ and O. Rusnak ${ }^{9}$. However, there are no separate scientific works devoted to the coverage of political upheavals and the agrarian question in Romania in the 1920s in the pages of the national-cerenist newspaper "Khliborobska Pravda". Therefore, in this paper, we will try to analyze this issue briefly.

To understand the political turmoil in the Kingdom of Romania at the time better, we will briefly describe the process of uniting these parties into a single opposition union. It should be noted that the realization of the need to preserve democracy forced the Cerenians to turn to an alliance with the National Party, and on April 23, 1926, both leaders signed and a few days later issued a Manifesto to the Country criticizing the National Liberals and calling for a national Cerenist bloc. If we take into account the actions of the government, the number of parties (25), the price of victory of those parties that have crossed the $2 \%$ mark increases. Thus, among them the first was the People's Party, which won 292 seats, 69 seats were won by the Cerenists, 16 - NLP and 10 - LNHZ. Alba (65.76\%), Cahul (62.81\%) and Fegerash $(62.31 \%)$ cast the most votes for the Cerenists, thus electing a total of 69 deputies in 54 counties. Central Bank organizations in territories with national minorities have had their successes. The Cerenians' idea that it was impossible to gain power solely by winning the parliamentary elections also became more stable, which forced them to make a final decision on merging with the National Party. It is worth noting that in the 1926 elections, the Ukrainians of Bukovina (representatives of the Ukrainian People's Democratic Party) opposed the Cerenist Party, calling it "the most chauvinistic" and intolerant of Ukrainians. The evidence was the absence of representatives of national minorities on the party's electoral list in Redeuc County, which was considered the largest community of national minorities ${ }^{10}$.

The decision-making process took two months. The nationalists gained supremacy, while the Cerenists played secondary roles in the leadership. Yu. Maniu became the chairman, V. Madzharu the general secretary,

${ }^{8}$ Піддубний І. Партії, парламент, король та уряд. Розвиток і взаємодія елементів політичної системи Румунії у 1918-1940 pр. Чернівці : Друк Арт, 2019. 912 с.

9 Руснак О. Реалізація положень румунської аграрної реформи в Північній Буковині та Хотинщині в міжвоєнний період. Вісник Прикарпатського університету. Історія. 2009. Вип. 16. С. 168-176.

10 Піддубний I. Партії, парламент, король та уряд. Розвиток і взаємодія елементів політичної системи Румунії у 1918-1940 pp. Чернівці : Друк Арт, 2019. C. 238. 
A. Vaida-Voevod, V. Breteshanu, I. Migalake, and Dr N. Lupu co-chairs. The candidacies of the heads of provincial and county organizations were also discussed.

At the same time, a meeting of the Permanent Delegation of the NP and the CEC of the Central Committee was held, which discussed the main provisions of the agreement, draft programs and statutes, and decided to hold party congresses on October 10, 1926, in Bucharest. At that time, the ceremonialist Dr N. Lupu, the nationalists N. Jorg, K. Argetoyan, and S. Popescu protested against the merger. Withdrawal from the party on the eve of the congress of taxi drivers, S. Popescu, and the Jorgists threatened the merger of the parties.

On October 10, 1926, the Congress of the National Party opened in the Transilvania Hall in Bucharest. In Maniu's speech, the history of the development of relations between the National and Cerenist parties was outlined, and the need for a merger was emphasized, as the party's forces were not sufficient to oppose the forces of the oligarchy. The party secretary read out the draft program and statute of the party and submitted a resolution to Congress in favour of the merger. After a brief discussion and reading of a letter from N. Jorga and a telegram from the county organization of Dolj opposing the merger, Congress approved the rapprochement of the National and Cerenist parties ${ }^{11}$.

A congress of the Cerenist Party took place in the Amiciţia Hall in Bucharest, attended by CEC members, parliamentarians, and delegations from 59 county organizations. I. Migalake announced the results of the discussion conducted by the Cerenists with J. Maniu and read the CEC resolution of September 26, 1926, after which he spoke in favour of the merger. He noted that there was nothing in the NCP program that would contradict the program of the Cerenist Party and that the new party would follow the same path and act by the same means as the Cerenist Party. He emphasized the importance of uniting the parties for the peasantry. After the speech of the party chairman V. Madzharu, he read the drafts of the program and the charter of the new party. Dr N. Lupu's speech in support of the program played a role, delegates declined to speak, and Congress voted in favour of the merger. After that, the delegations communicated, and the Cerenists arrived at the Congress of Nationalists, which formally completed the merger $^{12}$.

11 Піддубний I. Партії, парламент, король та уряд. Розвиток і взаємодія елементів політичної системи Румунії у 1918-1940 pр. Чернівці : Друк Арт, 2019. С. 238-239.

${ }^{12}$ Ibid. 
A few days after the congress, the Manifesto of the National Cerenist Party was issued, in which the association was explained by the will of many citizens and the need for time. They argued for the need to have a strong and independent government of representatives of people's and solidarity parties. They also analyzed the party's program and its charter.

The program of the new party should be assessed as almost a complete program of the Cerenist party because it is built on the main problems and tasks that this party set in previous years and included in the unification program in 1924. The first task was to solve the problem of the constitution, civil rights and freedoms. In the administrative issue, the task remained the decentralization of power, while in the field of justice - the creation of an independent judiciary with the unification of legislation. In the field of education, the main issue remained the elimination of illiteracy and the development of primary education, as well as improving the system of secondary and higher education and training. Concerning national minorities, the program was guided by the provisions of the Alba Iulia decision. Here the NCP was going to support both the Orthodox religion and other state-recognized cults. However, the church itself was to become autonomous and not interfere in politics. Freedom of faith was to be guaranteed ${ }^{13}$.

The economic program was based on the normalization of economic life, and agriculture, which was considered leading, refused to subordinate industry. The economic part of the program was practically divided into measures in agriculture, auxiliary agrarian reform, measures in industry, measures in commerce and cooperation. One of the highlights of the program, which was used for advocacy during the opposition period, was the provision to review the reform and determine the size of farms. Other industries close to agriculture were going to reform. In the financial sphere, they planned to stabilize the lei and introduce a balanced budget. The customs tariff policy also had to be revised. Improvements in rail transport, mail, telegraph, and telephone were also considered. Clause XI of the program provided for the use of foreign capital, which was to be equated in rights with the Romanian one ${ }^{14}$.

In labour policy, the program recommended recognizing unions as legal entities and "a means of communication between labour and capital". They set tasks to implement labour protection, create a system of assistance to

13 Піддубний I. Партії, парламент, король та уряд. Розвиток і взаємодія елементів політичної системи Румунії у 1918-1940 pр. Чернівці : Друк Арт, 2019. C. 239.

${ }^{14}$ Ibid. 
workers in old age, illness, disability, take measures against unemployment, set a minimum wage. Other social challenges included raising the level of health care. They considered it necessary to pursue a foreign peace policy, maintain existing alliances and act within the League of Nations ${ }^{15}$.

In 1926, a second large bourgeois party was formed, which continued its activities no longer in radical positions but did not relinquish its role as an opposition force. The NCP immediately launched a mass campaign demanding respect for and expansion of democratic rights and freedoms ${ }^{16}$.

\section{Political life in the newspaper}

Analyzing the topics related to political life, which were covered in the pages of "Khliborobska Pravda" at that time, we note that a lot of attention was paid to the upcoming parliamentary elections. In particular, the article "The Great Time has Come" (April 18, 1926) stated that the next elections were decisive and the fate of the democratic system in the Romanian state would depend on their results. Here is how it was stated: "In the event of the victory of the liberal deputies of the Averiscans, our people will remain enslaved in the yoke they have borne for many years. If the farmers' party wins, the era of true democracy will come to Romania, a time when all capitalists, lords who cannot live without lordly hands are afraid like the devil of sacred water". It was also said that the ruling government regime used various means to fight against opposition forces representing the interests of peasants living in different regions of Romanian state of that time. As noted in the publication, "to weaken the forces of the Farmers' Party, the gentlemen went to the services of enemies of the people, who want that of the millions that the gentlemen carve out of the blood and sweat of farmers fell and they have something and they go among the people only to confuse and deceive him"17.

Another topic that covered aspects of political life at the time was the process of merging the opposition forces of the Cerenist and National parties into a single entity, which we mentioned above. Indeed, the unification of these political structures was a challenge for the ruling government, as the union could potentially win a parliamentary majority in the future and form its cabinet. One issue of the newspaper "Khliborobska Pravda" stated that "the day of the unification of the agricultural and national parties will become a new page in the history of Romania. The main point in the new

15 Піддубний I. Партії, парламент, король та уряд. Розвиток і взаємодія елементів політичної системи Румунії у 1918-1940 pp. Чернівці : Друк Арт, 2019. C. 239.

${ }^{16}$ Ibid.

${ }^{17}$ «Настав великий час». Хліборобська правда. 1926. № 7. 18 квітня. С. 1. 
party program will be the revision of land reform. For the Ukrainian people, the main thing in their program is the rights of minorities. The merger of the two parties is a big step in the democratization of relations in Romania, and everyone urgently expects that relations in the country will improve in a short time" $" 18$. At the same time, not only the idea of revising agrarian reform was important for the leaders of these two parties, but also the preservation and development of democracy. The pages of the newspaper devoted to this political process stated that "the state can no longer tolerate the rule of a dictatorship. The best proof is the fact that instead of opening the parliament, the Averisculus government postponed it for a month"19. Of course, the words about the government's dictatorship are an exaggeration, but there is no doubt that adherence to the principles of a democratic system was one of the key foundations for the coalition of these parties.

The columns of "Khliborobska Pravda" actively covered important events in the political life of the Kingdom of Romania at that time. These include parliamentary discussions of bills on social or economic issues, government policy in one area or another, speeches by prominent politicians in the Romanian parliament, appointments to the executive branch, and so on. For example, the pages of the publication described in detail the situation around the formation of a multiparty government, which took place in the summer of 1927. Newspaper publications indicated that the change of most heads of various ministries was long overdue because they "kept the whole state under a heavy yoke" 20 . There were also criticisms of General Averescu's former government, which was forced to resign. Note that the editors paid attention to this event not only to gain popularity by criticizing the previous Cabinet of Ministers but also because the representatives of the National Cerenist opposition camp joined the new government and headed some ministries. In particular, M. Popovych was appointed the new Minister of Finance, G. Yunin the Minister of Labor, N. Lupu the Minister of Education, and S. Dan State Secretary of Finance (meaning the Treasury, which at that time functioned as a separate department - Author ${ }^{21,}$ There were also calls for the Ukrainian population living in Romania to refrain from voting in the upcoming elections for political structures associated with the former regime and personally with General Averescu, as "the Ukrainian people have no reason to vote for the Averians. All their promises and oaths turned out to be lies"22.

\footnotetext{
18 «Злука демократичних партій». Хліборобська правда. 1926. № 17. С. 1.

${ }^{19}$ Ibid.

${ }^{20}$ «Зміна правительства». Хліборобська правда. 1927. № 3.12 липня. С. 1.

${ }^{21}$ Ibid.

${ }^{22}$ Ibid.
} 
Another aspect of political life that needs to be covered is the critique of ideological opponents. This component was given a lot of space in the newspaper. Interestingly, the key political competitors for the National Cerenist bloc were the Liberals and the Social Democrats. It should be noted that the criticism of liberal political forces was connected with the ruling regimeof that time. After all, during the 1920s, most of the people in power in the executive branch belonged to this political camp. Therefore, it is not surprising why criticism of the Liberals was heard in the pages of all official publications of the national and Cerenist parties not only during this period but also in subsequent years. All miscalculations in domestic and foreign policy, shortcomings in the implementation of measures in the social or economic spheres were associated with liberal forces and their governments. Interestingly, in most cases, this criticism was also supported by the attitude of the Ukrainian population. It was usually pointed out that none of the ruling forces had been able to take into account the interests of Ukrainians in the agricultural field, in school education, language issues, and so on. These critical articles ended with a call for a future struggle and a reminder that the only party capable of defending the rights of Ukrainians in Bukovina and Bessarabia was the National Cerenist Union ${ }^{23}$.

Another political opponent was the Social Democrats. There was also a lot of criticism of these forces and their leaders, but it was due to other factors. It should be noted at once that the articles criticizing the ideological platform and actions of the Social Democrats did not divide the socialist and communist camps. The fact is that such a division was not carried out not only by the editors of "Khliborobska Pravda" but also by politicians of the National Cerenist Party. Although, as I. Piddubnyi, an expert on the political history of Romania in the interwar period, notes, the socialists and communists, although belonging to the left political camp and having a similar social base, were quite different in their ideological basis, organizational structure, and so on ${ }^{24}$.

Analyzing the criticism of the social-democratic forces, it should be divided into two components. The first is an ideological doctrine. It was she who caused a considerable number of critical remarks in the pages of this publication. Last but not least, these ideas were associated with actions in the political, socio-economic spheres, methods of combating political opponents, implemented by the Bolshevik government in the Soviet Union.

23 «Зміна правительства». Хліборобська правда. 1926. № 6. С. 1.

24 Піддубний I. Партії, парламент, король та уряд. Розвиток і взаємодія елементів політичної системи Румунії у 1918-1940 pp. Чернівці : Друк Арт, 2019. C. $316-438$. 
As noted in one of the newspaper publications devoted to the left parties, "the worst demagogues in our Bukovina are the Bolsheviks (meaning communists - Ed.) United around the "Borotba" ("The Struggle" a periodical of the Communists), who are with the Social Democrats". It was emphasized that they were all allies of the Bolsheviks and that their ideas, which were intended for an illiterate population, could not be put into practice. In addition, there were specific examples when the ideas and slogans of the Bolsheviks in the USSR never materialized. These are halfactions of the process of "Ukrainization", problems in the field of agriculture, industry, etc. ${ }^{25}$

The second component of the criticism was the ethnic origin of the representatives of the social democratic forces. According to the National Cerenists, most members of both the Socialist and Communist parties were Jews. Such considerations were voiced not only in "Khliborobska Pravda" but also in other official newspapers of the National Cerenist camp, which were published in the regions of the Kingdom of Romania. In newspaper articles of that period, such terms as "Jewish demagogues", "Jewish liars", "Jewish hirelings" were often used. On the one hand, such judgments were prompted by the conviction of nationalist activists that the socialist and communist movements in the Romanian state functioned through the financial income they received from the Soviet government. On the other hand, the level of anti-Semitism in Romania in the interwar period. AntiSemitic sentiments were widespread at the time. However, it should not be forgotten that this phenomenon was characteristic not only of this country, but also of the whole of Central and Eastern Europe in the years between the two world wars. In our opinion, it is worth agreeing with the assessments of Western researchers R. Gerwarth and J. Horne that anti-Semitism after the First World War was associated with the idea of "Bolshevik threat" that prevailed in the minds of many people in the region. In the imagination of the people of that time, Bolshevism was associated with the destruction of human civilization. Fantastic fears about the Bolsheviks, who sought to seize power in other countries, had a significant impact on the political ideas of the Europeans of the time. Fantasies about the onset of powerful nihilistic forces became the basis for the inspiration of conservative and counterrevolutionary forces in continental Europe ${ }^{26}$.

Thus, the political vicissitudes in the Romanian state of the second half of the 1920s occupied an important place in the pages of the official

${ }^{25}$ «Брехня». Хліборобська правда. 1927. № 12. С. 1-2.

${ }^{26}$ Gerwarth R., Horne J. War in Peace: Paramilitary Violence in Europe after the Great War. Oxford: Oxford University Press, 2012. 256 p. 
newspaper of the National Cerenists, "Khliborobska Pravda". These publications covered a wide range of issues, from intra-party processes within the national-cerenist coalition to criticism of the then ruling sociopolitical system, the government and the political forces that supported it.

\section{The agrarian question in the columns of the newspaper}

Much attention was also paid to the agrarian question in the columns of this periodical, but it was a key element of their ideological platform for the national cerenists. As for the aspects of coverage of this issue, they were different.

It should be noted that in the period under consideration, many newspaper articles were devoted to the critique of agrarian reform, which was implemented in the Kingdom of Romania in the early 1920s. For better understanding, we will analyze the characteristics of changes in the agricultural sector. It should be noted that the discussion of the draft agrarian law took place in the conditions of struggle in both chambers of parliament and against the background of the development of revolutionary events. It is possible that the latest processes forced the government to hurry and submit on February 21, 1921, to the Senate to draft laws on agrarian reform. The reluctance to carry out "mechanical expropriation" was one of the reasons for the gradation of large landholdings, as well as determining the size of the land allotment of peasant farms and farms of colonists. The law established the conditions for the formation of the price of land and the terms of payment for it by peasants. Although the imperfection of the law took place, the adoption of the law on agrarian reform was one of the achievements of the government of A. Averescu, which was used in further political struggle. During the implementation of the agrarian reform, $1,829,046$ hectares were expropriated and 357,015 peasants were used to provide land. The problem was the tax arrears, which amounted to more than 3.5 billion lei, most of which fell on farms up to 10 hectares. They tried to solve the problem with the help of the law on debt conversion, the introduction of which reduced debts to 1751 million $\mathrm{lei}^{27}$.

If we talk about the peculiarities of the implementation of agrarian reform in Bukovina and Bessarabia, it went through several stages: the establishment of institutions entrusted with the functions of expropriation of land from large landowners, churches, monasteries and foreign nationals and their transfer to landless or landless peasants; description of large estates and

27 Піддубний I. Партії, парламент, король та уряд. Розвиток і взаємодія елементів політичної системи Румунії у 1918-1940 pp. Чернівці : Друк Арт, 2019. C. 705 . 
redemption of surplus land; compilation of registers of applicants for additional, complete, colonization plots and their acquisition of land ownership $^{28}$.

Analyzing the criticism of the national ceremonials of agrarian reform, which was heard in the articles, we observe that one of the biggest shortcomings they considered was the unfair distribution of confiscated land among peasant farms. In some publications, they called on the peasants to address their complaints about the unequal division of power to the relevant authorities, the national-cerenist party structures, so that they could defend their rights and interests ${ }^{29}$.

The authors also paid attention to the reasons that forced the Romanian authorities to start the agrarian transformation. A special place in them was given to the events of the First World War and the revolutionary processes in Central and Eastern Europe. Thus, one of the articles in "Khliborobska Pravda" stated that "the year 1918 shook Eastern and Central Europe, revolutions broke out" and this was the reason why "the Romanian boyar authorities, surrounded by this, decided to give part of the land to the hungry peasantry. Only this circumstance was the reason that prompted the Romanian nobles to the so-called law of agrarian reforms" 30 . Of course, the unbalanced distribution of land was affected again, but the emphasis was on the fact that such a lack was caused not only by social reasons but also by ethnic origin, as other national communities - Hungarians, Jews and Ukrainians - lived in these lands of the Kingdom of Romania. For example, specific cases of such oppression were pointed out, and it was reiterated that Ukrainian peasants should only support nationalists, as they would be able to protect their interests ${ }^{31}$.

One of the topics that were actively raised in the pages of "Khliborobska Pravda" was the agrarian issue in Soviet Ukraine and the USSR in general. It aroused interest not only because the USSR and the Kingdom of Romania had a common border and the fact that Ukrainians in Bukovina and Bessarabia sought to learn more about life in Greater Ukraine. This interest was also caused by the fact that the national cerenists tried to comprehend the transformation in the agrarian sphere in the USSR, because, as we mentioned above, agrarian reform was a key component of the ideological

${ }^{28}$ Руснак О. Реалізація положень румунської аграрної реформи в Північній Буковині та Хотинщині в міжвоєнний період. Вісник Прикарпатського університету. Історія. 2009. Вип. 16. С. 169.

29 «В справі аграрної реформи». Хліборобська правда. 1926. № 16. 2 травня. C. $1-2$.

${ }^{30}$ «Все ще про земельну реформу». Хліборобська правда. 1928. № 18. С. 1.

${ }^{31}$ Ibid. 
platform of this political force. Fair changes in the agrarian sphere were considered by the national cerenists as a guarantee of successful development in the future. Therefore, such interest was quite understandable.

It should be noted that newspaper publications actively criticized the actions of the Bolsheviks in agricultural policy. It was pointed out that the ideological nature of the Bolshevik concept in this matter led to the fact that their measures did not find widespread support among the peasants. Without the support of the peasantry, the Soviet government would not have been able to retain power for long. Therefore, as it was rightly emphasized in the newspaper publications, "the Bolsheviks did not know how to satisfy the interests of the peasants and therefore the village in Russia and Ukraine remained a nest of dissatisfied people. And to satisfy the interests of the peasantry, the Bolshevik government renounced many of its radical reforms and put the agricultural question at the forefront of its domestic policy ${ }^{\prime 32}$. Moreover, realizing the utopian nature of its plans, the Soviet government returned to market management methods. As noted in the newspaper's columns, "the peasant question is the most important in today's Russia. That is why the Bolshevik government changed its course, returning to the "bourgeois mistress" ${ }^{\prime 3}$. According to the authors of the articles, the greatest dissatisfaction of the peasants was caused by their unequal relations with the Bolshevik authorities, economic troubles, and artificial underestimation of prices for agricultural products. In addition, some publications were devoted to the struggle of Ukrainian peasants and other social groups against the Soviet leadership. Cases of peasant resistance to Bolshevik policy in various regions of Soviet Ukraine, repression of Ukrainians by the authorities, and so on were mentioned $^{34}$.

The editors of "Khliborobska Pravda" were also attracted by the Bolshevik measures taken to gain loyalty among the peasantry. Among such actions of the Bolshevik government, the policy of "Ukrainization" aroused interest. Such a political course of the Soviet government was to ensure the spread of communist ideas among Ukrainian peasants. This policy, as rightly emphasized in the pages of the publication, "was one of the means of communist propaganda among the Ukrainian peasantry". However, even such steps by the Soviet leadership did not greatly increase the authority of the Ukrainian peasantry. After all, the Soviet government did not take into account the peculiarities of management on Ukrainian lands, which was formed over the centuries. In these territories, the collective form of

32 «Хліборобське питання в Сов. Росії». Хліборобська правда. 1926. № 15. 8 серпня. С. 2.

${ }^{33}$ Ibid.

${ }^{34}$ Боротьба проти советів на Україні. Хліборобська правда. 1927. № 1. С. 1. 
agriculture, in contrast to Russia, was not so common. Therefore, communist ideas about the creation of collective farms in Soviet Ukraine were opposed by peasants. Thus, in one of the newspaper reviews of the situation in the USSR on this occasion it was stated: "In Ukraine, in the vast majority, an individual form of land tenure prevailed, which could not but affect the psychology of the peasants. This explains the disobedience of the Ukrainian peasantry to the communist idea. That is why the communists turned their energy to the struggle against the Ukrainian peasant and his hostility to communist forms of land use" 35 .

Of course, the agrarian policy of other states also aroused interest. For example, many articles covered measures to address the agrarian issue in the states that emerged in the vastness of continental empires after the First World War. This is not surprising, since, in the interwar period, these newly created nation-states carried out agrarian transformations to eliminate the former imperial relations that dominated the field until 1914. In addition, we should not forget that in the period between world wars the positions of political forces the interests of the peasantry were quite strong in all the countries of Central and Eastern Europe.

It should be noted that an important place among the publications in "Khliborobska Pravda" was given to agrarian reform in Czechoslovakia. At that time, the reform of this area, which began after 1918, was almost completed.

Analyzing newspaper articles on this issue, we emphasize that readers had the opportunity to get acquainted with the key components of agrarian reform in the Czechoslovak Republic. The importance of these changes was discussed not only for the Czechoslovak government, but also for other political regimes in the region, the principles according to which this reform was implemented, the algorithm for its implementation, and so $\mathrm{on}^{36}$. In particular, the characteristic features of each stage of these agrarian transformations were indicated, and the activities of the institutions responsible for the course of the reform were detailed. Of course, we paid attention to the shortcomings that occurred in the process of these changes. For example, the negative impact of the bureaucracy on this reform was mentioned, because due to some amendments during each stage of these changes, the reform plan, which began to work on after the end of World War $1914-1918^{37}$, changed significantly. Considerable criticism has been

${ }^{35}$ Банкротство комуністичної ідеї на Україні. Хліборобська правда. 1927. № 6. С. 2.

${ }^{36}$ Аграрна реформа в Чехословаччині. Хліборобська правда. 1928. № 23. С. 1.

37 Аграрна реформа в Чехословаччині. Хліборобська правда. 1928. № 24. 17 червня. С. 1. 
levelled at the distribution of vacant land among the peasantry, as the land standards agreed upon in the agrarian reform project were often not met in practice, which in turn caused dissatisfaction among the peasant community ${ }^{38}$. It was also emphasized the slow pace of transformation of this area, the failure to implement the idea of creating collective farms in rural areas, which insisted on the left political forces of Czechoslovakia, and so on $^{39}$. Interestingly, the columns of the periodical mentioned the national component of agrarian reform, which also caused criticism. Thus, it was emphasized that the then Czechoslovak state was not monoethnic, because it was inhabited by other national communities - Slovaks, Germans, Poles, Ukrainians, Jews. However, preference was given to the Czechs in the distribution of land, although the above-mentioned ethnic minorities were able to manage the countryside no less productively ${ }^{40}$. In fairness, the authors tried to explain to readers such measures of the Czechoslovak government by the former oppression of the Czechs, which they suffered from the Germans and Hungarians during the existence of the Habsburg monarchy. As stated in one of the newspaper articles, "by carrying out land reform, they wanted to correct the wrongs done to the Czechs by the Germans and Hungarians several centuries ago ${ }^{41}$ ".

Another issue that has been given a place in "Khliborobskaya Pravda" is related to the agrarian issue but in the dimension of Central and Eastern Europe. This is the creation of an international platform that combines and coordinates the activities of peasant parties. Thus, the pages of the newspaper covered the work on the creation of such an institution, the so-called "farming international", as mentioned in the columns of the newspaper. This was the initiative of one of the most influential Czechoslovak politicians of the interwar period and leader of the Agrarian Party Antonin Schwegl (1873-1933). According to A. Schwegl, such a structure could in the future consolidate political forces in different regions of continental Europe, representing the interests of the peasantry, as well as allow to protect the rights of this social community at the global level. Such ideas attracted the support of Romanian nationalists. Publications on this subject stated: "The creation of the Farmers' International is of great importance for all farmers. We can only warmly welcome its creation" ${ }^{42}$.

38 Аграрна реформа в Чехословаччині. Хліборобська правда. 1928. № 24. 17 червня. С. 1.

${ }^{39}$ Ibid.

${ }^{40}$ Ibid. C. $1-2$.

41 Ibid.

42 «Хліборобський інтернаціонал». Хліборобська правда. 1928. № 17.22 квітня. C. 1 . 
However, as rightly noted below, only parties operating in their nation-states can be members of such an organization. Therefore, for example, Ukrainian conservative forces (supporters of Hetman P. Skoropadskyi) could not participate in its activities ${ }^{43}$.

\section{CONCLUSIONS}

Summing up, let's focus on some of our considerations. First, the subject of political life and the agrarian question occupied an important place in the publications of the Ukrainian edition of the national cerenists "Khliborobska Pravda". These topics, along with other current issues of the time (national, educational), aroused interest in the readership. Secondly, we believe that such thematic preferences were caused not only by the fact that the newspaper's editors focused more on the Ukrainians of Northern Bukovina and Northern Bessarabia, but also on their ideological and political convictions. After all, the same editorial policy is observed in other publications of this political force, which were published in other territories of the Kingdom of Romania at that time. Third, we can state that such an emphasis on the publishing activities of the national cerenists and their consideration of ethnic specificity was, on the one hand, evidence of their political ambitions and aspirations to form their government. On the other hand, it reflects the realities of the "short twentieth century", when the tools of "industrial civilization" (periodicals, radio, telegraph and other means of communication) were transformed into means of political struggle and the future of a political regime depended on their effective use.

\section{REFERENCES}

1. Аграрна реформа в Чехословаччині. Хліборобська правда. 1928. № 24. 17 червня. С. 1-2.

2. Банкротство комуністичної ідеї на Україні. Хліборобська правда. 1927. № 6. C. 1-2.

3. Боротьба проти советів на Україні. Хліборобська правда. 1927. № 1. C. 1-2.

4. Брехня. Хліборобська правда. 1927. № 12. С. 1-2.

5. В справі аграрної реформи. Хліборобська правда. 1926. № 16. 2 травня. С. $1-2$.

6. Все ще про земельну реформу. Хліборобська правда. 1928. № 18. C. $1-2$.

43 «Хліборобський інтернаціонал». Хліборобська правда. 1928. № 17. 22 квітня. C. 1 . 
7. Гобсбаум Е. Вік екстремізму. Коротка історія XX віку. 1914-1991. Київ : Альтернатива, 2001. 544 с.

8. Демагоги. Хліборобська правда. 1927. № 12. С. 1-2.

9. Злука демократичних партій. Хліборобська правда. 1926. № 17. C. $1-2$.

10. Зміна правительства. Хліборобська правда. 1926. № 6. С. 1-2.

11. Кобилянський С.Д. 3 історії проведення аграрної реформи на Північній Буковині під час окупації краю буржуазно-поміщицькою Румунією. Минуле і сучасне Північної Буковини. Київ : Наукова думка, 1972. Вип. 1. С. 40-51.

12. Литвинов В.К. Аграрная реформа на Буковине во время румынской оккупации 1921-1926. Тезисы докладов ХIII отчетной научной сессии профессорско-преподавательского состава. Черновицкий государственный ун-т. Черновцы, 1957. С. 69-70.

13. Литвинов В.К. Аграрная реформа на Буковине во время румынской оккупации 1921-1926. Тезисы докладов ХIII отчетной научной сессии профессорско-преподавательского состава. Черновицкий государственный ун-т. Черновцы, 1957. С. 69-70.

14. Литвинов В.К. Становище селян Буковини в боярській Румунії (1918-1939). Наукові записки ЧДУ. Серія історичних наук. Львів : Видво Львів, держ. ун-ту, 1956. Т. 18. С. 55-68.

15. Малинский В. Аграрная реформа 1918-1924 гг. в Бессарабии. Кишинев, 1949. 144 с.

16. Настав великий час. Хліборобська правда. 1926. № 7.18 квітня. C. $1-2$.

17. Піддубний I. Партії, парламент, король та уряд. Розвиток $\mathrm{i}$ взаємодія елементів політичної системи Румунії у 1918-1940 pp. Чернівці : Друк Арт, 2019.912 с.

18. Ротшильд Дж. Східно-Центральна Європа між двома світовими війнами. Київ : Мегатайп. 496 с.

19. Руснак О. Реалізація положень румунської аграрної реформи в Північній Буковині та Хотинщині в міжвоєнний період. Вісник Прикарпатського університету. Історія. 2009. Вип. 16. С. 168-176.

20. Хліборобське питання в Сов. Росії. Хліборобська правда. 1926. № 15.8 серпня. С. $1-2$.

21. Хліборобський інтернаціонал. Хліборобська правда. 1928. № 17. 22 квітня. С. 1.

22. Gerwarth R., Horne J. War in Peace: Paramilitary Violence in Europe after the Great War. Oxford : Oxford University Press, 2012. 256 p.

23. Nicolaescu A. Evoluţia editorială a gazetei Țărănismul în primii doi ani de existentă (1925-1927) Studia Universitatis Cibiniensis. Series Historica. 2018. № 15. P. 173-199. 